\title{
sciendo
}

\section{GROWTH PERFORMANCE, NUTRIENT DIGESTIBILITY, AND SELECTED FECAL MICROBIOTA ARE IMPROVED BY $\beta$-GLUCAN SUPPLEMENTATION IN WEANER PIGS}

\author{
Xin Jian Lei ${ }^{1,2}$, Hyeok Min Yun², Yi Yang ${ }^{2}$, In Ho Kim² \\ ${ }^{1}$ College of Biological Engineering, Henan University of Technology, No. 1 Lianhua Street, \\ Zhengzhou, 450001, China \\ ${ }^{2}$ Department of Animal Resource \& Science, Dankook University, No. 29 Anseodong, Cheonan, \\ Choongnam 330-714, South Korea \\ •Corresponding author: inhokim@dankook.ac.kr
}

\begin{abstract}
This study was conducted to evaluate the effects of dietary $\beta$-glucan supplementation on growth performance, nutrient digestibility, blood profiles, and fecal characteristics in weaner pigs. A total of 140 weaner pigs [(Yorkshire $\times$ Landrace) $\times$ Duroc] with an average body weight of 6.37 \pm 1.14 kg were allotted to one of the following dietary treatments: 1) negative control (NC, basal diet); 2) positive control (PC, basal diet supplemented with 39 ppm Tiamulin); 3) basal diet supplemented with $0.1 \% \beta$-glucan (G1); 4) basal diet supplemented with $0.2 \%$-glucan (G2). During days 22 to 42 and 1 to 42, pigs offered PC and G2 diets grew faster than those offered $\mathrm{NC}$ diet $(\mathrm{P}<0.05)$. Additionally, during the same periods, pigs fed G2 and PC diets exhibited improved gain:feed ratio compared to pigs receiving $\mathrm{NC}$ and $\mathrm{G} 1$ diets $(\mathrm{P}<0.05)$. Pigs fed $\mathrm{G} 2$ diet exhibited higher coefficient of total tract apparent digestibility of dry matter than those fed $\mathrm{NC}$ diet $(\mathrm{P}<0.05)$. There were no differences on blood profiles, fecal scores, fecal moisture, and fecal $\mathrm{pH}(\mathrm{P}>0.05)$. Fecal lactic acid bacteria counts in G2 treatment were higher compared with PC and NC treatments $(\mathbf{P}<\mathbf{0 . 0 5})$. Coliform bacteria concentrations were decreased in pigs fed $\mathrm{PC}$ and $\mathrm{G} 2$ diets compared with those fed $\mathrm{NC}$ diet $(\mathrm{P}<\mathbf{0 . 0 5})$. In conclusion, the results of the current study indicate that dietary supplementation of $0.2 \% \beta$-glucan can improve growth performance and dry matter digestibility, increase fecal lactic acid bacteria concentration but decrease fecal coliform bacteria concentration in weaner pigs.
\end{abstract}

Key words: $\beta$-glucan, digestibility, growth performance, weaner pigs

Many countries including European Union countries and South Korea have banned the use of antibiotic as growth promoters (AGPs) in feed due to the antibiotic residues in animal products and bacterial resistance (Salim et al., 2013; Levy, 2014). Therefore, high interest is now being paid to alternative to AGPs to improve disease resistance and enhance growth performance in pig production (Ke et al., 2014; Men- 
del et al., 2017). Probiotics, prebiotics, enzymes, acidifiers, herbs, and plant extracts are the most widely researched potential alternatives to AGPs (Thacker, 2013; Cheng et al., 2014).

Prebiotics are indigestible substances that allow specific changes in the composition and/or activity of gastrointestinal microbiota, which elicits positive effects on growth performance and health status of the host (Ducatelle et al., 2015). $\beta$-glucans are polymers of glucose linked by $\beta-1,3$ and $\beta-1,6$ glycosidic linkages that can be derived from the cell walls of yeast, bacteria, fungi, and cereal grains such as oats, barley, and rye (Huff et al., 2006; Metzler-Zebeli et al., 2012). Currently, $\beta$-glucan has been of interest as a potential prebiotic in swine nutrition. In pigs, supplementation of $\beta$-glucan was reported to improve growth performance, immune function, and intestinal microbial balance (Dritz et al., 1995; Murphy et al., 2013). However, conflicting findings regarding the effects of $\beta$-glucan supplementation were observed. Mao et al. (2005) and Zhou et al. (2013) found that supplementation of $\beta$-glucan had no effects on growth performance but increased immune function in weaner pigs. We hypothesized that dietary $\beta$-glucan could alleviate post-weaning diarrhea, improve intestinal microbial balance, increase nutrient digestibility, thereby improving growth performance in weaner pigs. Thus, the objective of this study was to investigate the effects of $\beta$-glucan on growth performance, nutrient digestibility, blood profiles, fecal $\mathrm{pH}$, fecal moisture, and fecal microbial shedding in weaner pigs.

\section{Material and methods}

The experimental protocol of the current study was approved by the Animal Care and Use Committee of Dankook University.

\section{Experimental design, animals and diets}

In total, 140 crossbred [(Yorkshire $\times$ Landrace $) \times$ Duroc] weaner pigs with an average body weight (BW) of $6.37 \pm 1.14 \mathrm{~kg}$ were randomly assigned to 4 experimental dietary treatments with 7 replications per treatment based on BW and sex (3 gilts and 2 barrows per pen). Dietary treatments included: 1) negative control (NC, basal diet); 2) positive control (PC, basal diet supplemented with $39 \mathrm{ppm}$ Tiamulin); 3) basal diet supplemented with $0.1 \% \beta$-glucan $(\mathrm{G} 1)$; 4) basal diet supplemented with $0.2 \%$ $\beta$-glucan (G2). The $\beta$-glucan (DMJ Biotech Co., Ltd., Yeongi-gun, Chungcheongnam-do, South Korea) used in this study was derived from Agrobacterium spp. R259 KCTC 10197B and guaranteed to contain $86.1 \% \beta-1,3 / 1,6$-glucan, $4.2 \%$ protein, and $1.3 \%$ lipids. The concentrations of $\beta$-glucan used in this study were modified from the results of Zhang et al. (2012). Dietary Tiamulin as an antibiotic has been demonstrated to improve growth performance in weaner pigs (Cho and Kim, 2015). Thus, in the present study, we selected supplementation of Tiamulin as a positive control to determine the effects of $\beta$-glucan in weaner pigs. The additives were added in the diets at the expense of the same amounts of corn. The diets were formulated to meet or exceed the NRC (2012) nutrient requirements (Table 1). The form of our experimental feed was mash. Pens were equipped with a multiple-space self- 
feeder, a nipple drinker and plastic slatted flooring. Pigs had free access to feed and water during the entire 42-day experiment. The ambient temperature within the room was controlled at $30^{\circ} \mathrm{C}$ for the first week and reduced by $1{ }^{\circ} \mathrm{C}$ per week thereafter.

Table 1. Feed compositions of basal diet (as-fed basis)

\begin{tabular}{|c|c|c|}
\hline Item & $\begin{array}{c}\text { Phase } 1 \\
\text { (days } 1 \text { to } 14 \text { ) }\end{array}$ & $\begin{array}{c}\text { Phase } 2 \\
\text { (days } 15 \text { to } 42 \text { ) }\end{array}$ \\
\hline \multicolumn{3}{|l|}{ Ingredient (\%) } \\
\hline corn & 44.49 & 61.97 \\
\hline soybean meal & 21.20 & 27.80 \\
\hline fish meal & 3.50 & - \\
\hline soy oil & 2.55 & 1.05 \\
\hline lactose & 8.30 & - \\
\hline whey & 10.00 & 5.00 \\
\hline dicalcium phosphate & 1.5 & 1.5 \\
\hline sugar & 3.00 & - \\
\hline plasma powder & 3.00 & - \\
\hline L-Lys $\mathrm{HCl}$ & 0.39 & 0.46 \\
\hline DL-Met & 0.30 & 0.24 \\
\hline L-Thr & 0.19 & 0.20 \\
\hline choline chloride & 0.10 & 0.10 \\
\hline vitamin $_{\text {premix }}{ }^{1}$ & 0.10 & 0.10 \\
\hline trace mineral premix ${ }^{2}$ & 0.20 & 0.20 \\
\hline limestone & 0.98 & 1.13 \\
\hline salt & 0.20 & 0.25 \\
\hline \multicolumn{3}{|l|}{ Calculated composition (\%) } \\
\hline $\mathrm{ME}(\mathrm{kcal} / \mathrm{kg})$ & 3540 & 3410 \\
\hline $\mathrm{CP}$ & 20.00 & 19.00 \\
\hline Lys & 1.50 & 1.35 \\
\hline Met & 0.62 & 0.53 \\
\hline Met + Cys & 0.97 & 0.84 \\
\hline $\mathrm{Ca}$ & 0.95 & 0.90 \\
\hline total P & 0.75 & 0.70 \\
\hline available $\mathrm{P}$ & 0.55 & 0.43 \\
\hline crude fat & 5.02 & 3.98 \\
\hline crude fiber & 1.87 & 2.45 \\
\hline \multicolumn{3}{|l|}{ Analyzed composition (\%) } \\
\hline crude protein & 20.11 & 18.96 \\
\hline $\mathrm{Ca}$ & 0.93 & 0.80 \\
\hline total $\mathrm{P}$ & 0.76 & 0.68 \\
\hline
\end{tabular}

'Provided per kg of complete diet: vitamin A - 11,025 IU; vitamin $\mathrm{D}_{3}-1,103 \mathrm{IU}$; vitamin E - 44 IU; vitamin K - $4.4 \mathrm{mg}$; riboflavin - $8.3 \mathrm{mg}$; niacin - $50 \mathrm{mg}$; thiamine - $4 \mathrm{mg}$; d-pantothenic acid - $29 \mathrm{mg}$; choline $166 \mathrm{mg}$; and vitamin $\mathrm{B}_{12}-33 \mu \mathrm{g}$.

${ }^{2}$ Provided per $\mathrm{kg}$ of complete diet: $\mathrm{Cu}\left(\right.$ as $\left.\mathrm{CuSO}_{4} \cdot 5 \mathrm{H}_{2} \mathrm{O}\right)-12 \mathrm{mg} ; \mathrm{Zn}\left(\right.$ as $\left.\mathrm{ZnSO}_{4}\right)-85 \mathrm{mg} ; \mathrm{Mn}\left(\right.$ as $\left.\mathrm{MnO}_{2}\right)-$ $8 \mathrm{mg}$; I (as $\mathrm{KI})-0.28 \mathrm{mg}$; and $\mathrm{Se}\left(\right.$ as $\left.\mathrm{Na} 2 \mathrm{SeO}_{3} \cdot 5 \mathrm{H}_{2} \mathrm{O}\right)-0.15 \mathrm{mg}$. 


\section{Experimental procedures and sampling}

Individual body weight and feed consumption on a pen basis were recorded on days $1,7,21$, and 42 of the experiment to calculate average daily gain (ADG), average daily feed intake (ADFI) and gain:feed ratio (G:F).

From days 1 to 7,15 to 21 and 36 to 42, pigs were fed diets mixed with chromic oxide $(0.2 \%)$ as an indigestible marker to determine the coefficient of total tract apparent digestibility (CATTD) for dry matter (DM), nitrogen $(\mathrm{N})$ and gross energy (GE) (Fenton and Fenton, 1979). On days 7, 21, and 42, fecal samples were collected from same 2 pigs ( 1 gilt and 1 barrow) in each pen via rectal massage. Fecal samples from the same pen were pooled and mixed, after which samples were stored at $-20^{\circ} \mathrm{C}$ until subsequent analyses were conducted. For chemical analysis, fecal samples were oven-dried at $60^{\circ} \mathrm{C}$ for $72 \mathrm{~h}$, after which feed and fecal samples were ground to pass through a 1.0-mm screen for analysis of DM (method 930.15) and N (method 984.13) using the AOAC (2007) procedures. Gross energy was determined by measuring the heat of combustion in the samples, using a bomb calorimeter (Parr 6100; Parr Instrument Co., Moline, IL, USA). Chromium was analyzed via UV absorption spectrophotometry (UV-1201, Shimadzu Corp., Kyoto, Japan), according to the method described by Williams et al. (1962). The CATTD was then calculated using the following formula:

$$
\text { CATTD }(\%)=[1-\{(N f \times C d) /(N d \times C f)\}] \times 100
$$

where:

$N f=$ nutrient concentration in feces $(\% \mathrm{DM})$,

$N d=$ nutrient concentration in $\operatorname{diet}(\% \mathrm{DM})$,

$C d=$ chromium concentration in $\operatorname{diet}(\% \mathrm{DM})$,

$C f=$ chromium concentration in feces $(\% \mathrm{DM})$.

For fecal $\mathrm{pH}$ and moisture determination, fresh feces were collected from each pen (fecal samples were collected from same 2 pigs served for digestibility sampling) via rectum massaging. The $\mathrm{pH}$ of the fecal samples was measured immediately after collection using a pH meter (model Accumet Basic, Fisher Scientific, Pittsburgh, PA, USA). Total moisture was determined by air-drying the collection at $60^{\circ} \mathrm{C}$, followed by an equilibration and moisture determination at $105^{\circ} \mathrm{C}$ (Harris, 1970).

Subjective fecal score was recorded for clinical signs of diarrhea at $0800 \mathrm{~h}$ each morning throughout the experiment by a single blinded observer, using the 5-grade scoring system described by O'Shea et al. (2014). Briefly, 1 = well-firmed feces; 2 = slightly soft feces; 3 = soft and partially formed feces; 4 = loose and semi-liquid feces (diarrhea); 5 = watery and mucus-like feces (severe diarrhea).

The blood samples were collected from the cervical vein into both $\mathrm{K}_{3}$ EDTA vacuum tubes and clot activator vacuum tubes (Becton Dickinson Vacutainer Systems, Franklin Lakes, NJ, USA) from 2 pigs (fecal samples were collected from same two pigs served for digestibility sampling) in each pen on days 1, 21, 42 to obtain whole blood and serum, respectively. The blood samples were then centrifuged at 3,000 $\times \mathrm{g}$ at $4^{\circ} \mathrm{C}$ for $20 \mathrm{~min}$ within 1 hour of collection to separate the serum samples. The 
concentration of immunoglobulin $\mathrm{G}(\mathrm{IgG})$ in the serum was measured using the automatic biochemistry analyzer (HITACHI 747, Tokyo, Japan). The concentration of white blood cells (WBC), red blood cells (RBC) and lymphocytes in the whole blood samples were determined using an automatic blood analyzer (ADVIA 120, Bayer, Tarrytown, NY, USA).

Fecal samples were collected directly via massaging the rectum of two pigs (fecal samples were collected from same two pigs served for digestibility sampling) from each pen on day 42. They were then pooled and transported to the laboratory where microbial analysis was immediately carried out. One gram of composite fecal sample from each pen was diluted with $9 \mathrm{~mL}$ of $1 \%$ peptone broth (Becton, Dickinson and Co., Franklin Lakes, NJ, USA) and then homogenized. Viable counts of bacteria in fecal samples were obtained by plating serial 10 -fold dilutions (in $1 \%$ peptone solution) onto MacConkey agar plates (Difco Laboratories, Detroit, MI) and lactobacilli medium III agar plates (Medium 638, DSMZ, Braunschweig, Germany) to isolate coliform bacteria and lactic acid bacteria, respectively. The lactobacilli medium III agar plates were incubated at $39^{\circ} \mathrm{C}$ for $48 \mathrm{~h}$ under anaerobic conditions. The MacConkey agar plates were incubated at $37^{\circ} \mathrm{C}$ for $24 \mathrm{~h}$. The numbers of coliform bacteria and lactic acid bacteria colonies were counted immediately after removing the plates from the incubator. The counts of coliform bacteria and lactic acid bacteria colonies were expressed as $\log 10$ of colony-forming units per gram of fecal sample.

\section{Statistical analyses}

All data were analyzed using the General Linear Model procedure of SAS (SAS Institute Inc., Cary, NC, USA). The pen was used as the experimental unit. Differences between treatments were detected by Tukey's multiple range test. The data were presented as means and pooled standard error of the mean. Significance was defined as $\mathrm{P}<0.05$.

\section{Results}

\section{Growth performance}

Pigs on G2 treatment had better G:F than those on NC treatment during days 1 to 7 ( $\mathrm{P}<0.05$; Table 2). During the days 8 to 21 , there were no treatment effects on growth performance $(\mathrm{P}>0.05)$. During days 22 to 42 and 1 to 42 , pigs offered $\mathrm{PC}$ and $\mathrm{G} 2$ diets grew faster than those offered $\mathrm{NC}$ diet $(\mathrm{P}<0.05)$. Additionally, during the same periods, pigs on $\mathrm{G} 2$ and $\mathrm{PC}$ diets exhibited improved $\mathrm{G}: \mathrm{F}$ compared to pigs receiving $\mathrm{NC}$ and $\mathrm{G} 1$ diets $(\mathrm{P}<0.05)$. No difference on $\mathrm{ADFI}$ was found throughout the experiment $(\mathrm{P}>0.05)$.

\section{Apparent total tract digestibility}

Pigs fed G2 diet exhibited beneficial effects on CATTD of DM digestibility in week $6(\mathrm{P}<0.05$; Table 3$)$. However, the CATTD of $\mathrm{N}$ and GE were not affected by dietary treatments $(\mathrm{P}>0.05)$. 
Table 2. Effects of $\beta$-glucan on average daily gain (ADG), average daily feed intake (ADFI), and gain:feed ratio (G:F) in weaner pigs in a 42-day feeding trial ${ }^{1}$

\begin{tabular}{|c|c|c|c|c|c|c|}
\hline \multirow{2}{*}{ Item } & \multicolumn{4}{|c|}{ Dietary treatments } & \multirow{2}{*}{ SEM $^{5}$} & \multirow{2}{*}{ P-value } \\
\hline & $\mathrm{NC}^{1}$ & $\mathrm{PC}^{2}$ & $\mathrm{G} 1^{3}$ & $\mathrm{G} 2^{4}$ & & \\
\hline \multicolumn{7}{|l|}{ Days 1 to 7} \\
\hline $\operatorname{ADG}(\mathrm{g} / \mathrm{d})$ & 222 & 242 & 257 & 258 & 19 & 0.523 \\
\hline $\operatorname{ADFI}(g / d)$ & 329 & 322 & 334 & 325 & 5 & 0.068 \\
\hline G:F & $0.676 \mathrm{~b}$ & $0.752 \mathrm{ab}$ & $0.770 \mathrm{ab}$ & $0.794 \mathrm{a}$ & 0.036 & 0.035 \\
\hline \multicolumn{7}{|l|}{ Days 8 to 21} \\
\hline $\operatorname{ADG}(\mathrm{g} / \mathrm{d})$ & 397 & 446 & 429 & 457 & 20 & 0.170 \\
\hline $\operatorname{ADFI}(\mathrm{g} / \mathrm{d})$ & 626 & 632 & 647 & 631 & 22 & 0.694 \\
\hline $\mathrm{G}: \mathrm{F}$ & 0.643 & 0.706 & 0.663 & 0.724 & 0.029 & 0.141 \\
\hline \multicolumn{7}{|l|}{ Days 22 to 42} \\
\hline $\operatorname{ADG}(\mathrm{g} / \mathrm{d})$ & $528 \mathrm{~b}$ & $584 \mathrm{a}$ & $558 \mathrm{ab}$ & $590 \mathrm{a}$ & 19 & 0.010 \\
\hline ADFI (g/d) & 852 & 840 & 877 & 851 & 34 & 0.871 \\
\hline $\mathrm{G}: \mathrm{F}$ & $0.620 \mathrm{~b}$ & $0.695 \mathrm{a}$ & $0.636 \mathrm{~b}$ & $0.692 \mathrm{a}$ & 0.011 & 0.001 \\
\hline \multicolumn{7}{|l|}{ Days 1 to 42} \\
\hline ADG (g/d) & $433 \mathrm{~b}$ & $481 \mathrm{a}$ & $464 \mathrm{ab}$ & $490 \mathrm{a}$ & 14 & 0.006 \\
\hline ADFI (g/d) & 690 & 684 & 710 & 690 & 23 & 0.741 \\
\hline G:F & $0.629 \mathrm{~b}$ & $0.703 \mathrm{a}$ & $0.654 b$ & $0.711 \mathrm{a}$ & 0.012 & 0.001 \\
\hline
\end{tabular}

$\mathrm{a}, \mathrm{b}$ - values in the same row with different letters differ significantly $(\mathrm{P}<0.05)$.

${ }^{1} \mathrm{NC}$ : negative control: basal diet.

${ }^{2} \mathrm{PC}$ : positive control: basal diet with $39 \mathrm{ppm}$ Tiamulin.

${ }^{3} \mathrm{G} 1$ : basal diet with $0.1 \% \beta$-glucan.

${ }^{4} \mathrm{G} 2$ : basal diet with $0.2 \% \beta$-glucan.

${ }^{5}$ SEM: standard error of the mean.

Table 3. Effects of $\beta$-glucan on the coefficient of total tract apparent digestibility of dry matter, nitrogen, and gross energy in weaner pigs

\begin{tabular}{|c|c|c|c|c|c|c|}
\hline \multirow{2}{*}{ Item (\%) } & \multicolumn{4}{|c|}{ Dietary treatments } & \multirow{2}{*}{$\mathrm{SEM}^{5}$} & \multirow{2}{*}{ P-value } \\
\hline & $\mathrm{NC}^{1}$ & $\mathrm{PC}^{2}$ & $\mathrm{G}^{3}{ }^{3}$ & $\mathrm{G}^{4}{ }^{4}$ & & \\
\hline \multicolumn{7}{|l|}{ Week 1} \\
\hline dry matter & 81.73 & 82.05 & 82.15 & 82.09 & 0.24 & 0.605 \\
\hline nitrogen & 82.62 & 82.83 & 82.39 & 82.33 & 0.34 & 0.790 \\
\hline gross energy & 82.63 & 83.31 & 83.32 & 82.97 & 0.22 & 0.801 \\
\hline \multicolumn{7}{|l|}{ Week 3} \\
\hline dry matter & 81.14 & 81.17 & 81.48 & 81.65 & 0.35 & 0.721 \\
\hline nitrogen & 81.62 & 81.74 & 82.00 & 81.89 & 0.48 & 0.256 \\
\hline gross energy & 82.19 & 82.38 & 82.57 & 82.41 & 0.34 & 0.359 \\
\hline \multicolumn{7}{|l|}{ Week 6} \\
\hline dry matter & $79.98 \mathrm{~b}$ & $81.59 \mathrm{ab}$ & $80.05 \mathrm{ab}$ & $82.46 \mathrm{a}$ & 0.21 & 0.035 \\
\hline nitrogen & 81.96 & 82.66 & 82.89 & 82.17 & 0.38 & 0.552 \\
\hline gross energy & 82.51 & 82.85 & 82.91 & 82.80 & 0.19 & 0.221 \\
\hline
\end{tabular}

$\mathrm{a}, \mathrm{b}-$ values in the same row with different letters differ significantly $(\mathrm{P}<0.05)$.

${ }^{1} \mathrm{NC}$ : negative control: basal diet.

${ }^{2} \mathrm{PC}$ : positive control: basal diet with $39 \mathrm{ppm}$ Tiamulin.

${ }^{3} \mathrm{G} 1$ : basal diet with $0.1 \% \beta$-glucan.

${ }^{4} \mathrm{G} 2$ : basal diet with $0.2 \% \beta$-glucan.

${ }^{5}$ SEM: standard error of the mean. 
Table 4. Effects of $\beta$-glucan on blood immunoglobulin $\mathrm{G}$ (IgG), red blood cell (RBC), white blood cell (WBC), and lymphocyte in weaner pigs

\begin{tabular}{|c|c|c|c|c|c|c|}
\hline \multirow{2}{*}{ Item } & \multicolumn{4}{|c|}{ Dietary treatments } & \multirow{2}{*}{$\mathrm{SEM}^{5}$} & \multirow{2}{*}{ P-value } \\
\hline & $\mathrm{NC}^{1}$ & $\mathrm{PC}^{2}$ & $\mathrm{G}^{3}{ }^{3}$ & $\mathrm{G} 2^{4}$ & & \\
\hline \multicolumn{7}{|l|}{$\overline{\mathrm{IgG}}(\mathrm{mg} / \mathrm{dL})$} \\
\hline day 1 & 308 & 278 & 315 & 280 & 35 & 0.512 \\
\hline day 7 & 285 & 264 & 256 & 242 & 65 & 0.288 \\
\hline day 21 & 312 & 324 & 314 & 319 & 40 & 0.921 \\
\hline day 42 & 421 & 416 & 441 & 430 & 39 & 0.354 \\
\hline \multicolumn{7}{|l|}{$\operatorname{RBC}\left(10^{6} / \mu \mathrm{l}\right)$} \\
\hline day1 & 6.46 & 6.37 & 6.20 & 6.64 & 0.15 & 0.475 \\
\hline day 7 & 6.48 & 6.13 & 6.60 & 6.33 & 0.21 & 0.895 \\
\hline day 21 & 6.87 & 6.45 & 6.33 & 6.73 & 0.33 & 0.454 \\
\hline day 42 & 6.70 & 6.92 & 6.87 & 6.59 & 0.42 & 0.398 \\
\hline \multicolumn{7}{|l|}{$\operatorname{WBC}\left(10^{3} / \mu \mathrm{l}\right)$} \\
\hline day 1 & 10.97 & 11.53 & 10.30 & 12.15 & 1.51 & 0.364 \\
\hline day 7 & 15.85 & 17.62 & 17.91 & 17.36 & 1.84 & 0.745 \\
\hline day 21 & 19.70 & 19.23 & 21.22 & 19.06 & 1.57 & 0.841 \\
\hline day 42 & 17.44 & 18.39 & 18.79 & 19.19 & 2.95 & 0.936 \\
\hline \multicolumn{7}{|c|}{ Lymphocyte (\%) } \\
\hline day 1 & 54.38 & 55.76 & 53.48 & 55.72 & 3.93 & 0.611 \\
\hline day 7 & 42.15 & 44.27 & 42.78 & 41.92 & 4.99 & 0.679 \\
\hline day 21 & 47.28 & 47.57 & 48.18 & 48.34 & 2.49 & 0.457 \\
\hline day 42 & 54.38 & 56.70 & 54.95 & 56.08 & 4.28 & 0.947 \\
\hline
\end{tabular}

${ }^{1} \mathrm{NC}$ : negative control: basal diet.

${ }^{2} \mathrm{PC}$ : positive control: basal diet with $39 \mathrm{ppm}$ Tiamulin.

${ }^{3} \mathrm{G} 1$ : basal diet with $0.1 \% \beta$-glucan.

${ }^{4} \mathrm{G} 2$ : basal diet with $0.2 \% \beta$-glucan

${ }^{5} \mathrm{SEM}$ : standard error of the mean.

Table 5. Effects of $\beta$-glucan on fecal score, moisture, $\mathrm{pH}$, and microbial shedding in weaner pigs

\begin{tabular}{|c|c|c|c|c|c|c|}
\hline \multirow{2}{*}{ Items } & \multicolumn{4}{|c|}{ Dietary treatments } & \multirow{2}{*}{$\mathrm{SEM}^{5}$} & \multirow{2}{*}{ P-value } \\
\hline & $\mathrm{NC}^{1}$ & $\mathrm{PC}^{2}$ & $\mathrm{G} 1^{3}$ & $\mathrm{G} 2^{4}$ & & \\
\hline \multicolumn{7}{|l|}{ Fecal score $^{6}$} \\
\hline days 1 to 7 & 3.20 & 3.29 & 3.16 & 3.26 & 0.07 & 0.851 \\
\hline days 8 to 14 & 2.78 & 2.80 & 2.85 & 2.78 & 0.09 & 0.725 \\
\hline \multicolumn{7}{|l|}{ Fecal moisture (\%) } \\
\hline day 7 & 71.84 & 71.61 & 72.32 & 71.75 & 0.64 & 0.513 \\
\hline day 21 & 73.18 & 72.91 & 73.58 & 73.27 & 0.61 & 0.714 \\
\hline day 42 & 74.23 & 68.34 & 75.29 & 71.17 & 3.88 & 0.359 \\
\hline \multicolumn{7}{|l|}{ Fecal pH } \\
\hline day 7 & 6.20 & 6.28 & 6.23 & 6.21 & 0.03 & 0.632 \\
\hline day 21 & 6.22 & 6.20 & 6.20 & 6.19 & 0.06 & 0.784 \\
\hline day 42 & 6.07 & 6.02 & 6.00 & 6.00 & 0.04 & 0.611 \\
\hline \multicolumn{7}{|c|}{ Fecal microbial shedding (log $\mathrm{cfu} / \mathrm{g})$} \\
\hline lactic acid bacteria & $6.32 \mathrm{~b}$ & $6.28 \mathrm{~b}$ & $6.48 \mathrm{ab}$ & $6.70 \mathrm{a}$ & 0.13 & 0.001 \\
\hline coliform bacteria & $6.32 \mathrm{a}$ & $6.05 \mathrm{~b}$ & $6.27 \mathrm{ab}$ & $6.09 \mathrm{~b}$ & 0.08 & 0.028 \\
\hline
\end{tabular}

$\mathrm{a}, \mathrm{b}$ - values in the same row with different letters differ significantly $(\mathrm{P}<0.05)$.

${ }^{1} \mathrm{NC}$ : negative control: basal diet.

${ }^{2} \mathrm{PC}$ : positive control: basal diet with $39 \mathrm{ppm}$ Tiamulin.

${ }^{3} \mathrm{G} 1$ : basal diet with $0.1 \% \beta$-glucan.

${ }^{4} \mathrm{G} 2$ : basal diet with $0.2 \% \beta$-glucan.

${ }^{5}$ SEM: standard error of the mean.

${ }^{6}$ Fecal score: 1 = well-firmed feces; 2 = slightly soft feces; 3 = soft and partially formed feces; $4=$ loose and semi-liquid feces (diarrhea); 5 = watery and mucus-like feces (severe diarrhea). 


\section{Blood and fecal parameters}

There were no differences on IgG, RBC, WBC, and lymphocyte concentrations among dietary treatments throughout the experiment (Table 4). No significant differences were observed on fecal scores, fecal moisture, and fecal $\mathrm{pH}$ (Table 5; $\mathrm{P}>0.05$ ). Fecal lactic acid bacteria counts in G2 treatment were higher compared with $\mathrm{PC}$ and $\mathrm{NC}$ treatments $(\mathrm{P}<0.05)$. Coliform bacteria counts were decreased in pigs fed $\mathrm{PC}$ and $\mathrm{G} 2$ diets compared with these fed $\mathrm{NC} \operatorname{diet}(\mathrm{P}<0.05)$.

\section{Discussion}

Beneficial effects of $\beta$-glucan on growth performance have been observed by Dritz et al. (1995). Results of the present study showed that $0.1 \% \beta$-glucan supplementation showed only a numerical improvement in growth performance. However, administration of $0.2 \% \beta$-glucan caused increased ADG during days 22 to 42 and 1 to 42 and improved G:F during days 1 to 7, 22 to 42 , and 1 to 42 compared with NC dietary treatment, although ADFI was not affected throughout the experiment. These observations agreed with the previous experiment reporting that dietary $\beta$-glucan supplementation improved ADG and G:F in weaner pigs, whereas $\beta$-glucan had no effect on ADFI in weaner pigs (Wang et al., 2008 a). Li et al. (2006) reported that supplementation of Saccharomyces cerevisiae $\beta$-glucan to weaner pigs challenged with Escherichia coli improved ADG but had not effects on ADFI and G:F, which is similar to some of our observations. However, growth performance response to $\beta$-glucan has been shown to be variable by other experiments. Hiss and Sauerwein (2003) observed that consumption of $\beta$-glucan $(0.015 \%$ and $0.03 \%)$ derived from Saccharomyces cerevisiae had no effects on growth performance in weaner pigs, although numerical improvements on ADG and ADFI were observed. Mao et al. (2005) observed that growth performance was not improved when Astragalus membranaceus $\beta$-glucan was included at the levels of $0.05 \%$ or $0.10 \%$ in weaner pigs diet. Sweeney et al. (2012) suggested that $\beta$-glucans derived from Laminaria digitata, Laminaria hyperborea and Saccharomyces cerevisiae had no effect on growth performance of weaner pigs. The inconsistent results may be caused by differences in hygienic conditions and the differences in source or dosage of $\beta$-glucan in different studies (Hiss and Sauerwein, 2003; Li et al., 2005). Additionally, in the present study, the pigs fed diet supplemented with $0.2 \% \beta$-glucan or Tiamulin obtained similar ADG, ADFI, and G:F. The comparable effects of $0.2 \% \beta$-glucan and Tiamulin on the growth performance indicate that $\beta$-glucan may be a potential candidate as an alternative to AGPs.

In the present study, addition of $\beta$-glucan or Tiamulin to weaner pigs diets had no effects on CATTD of DM, GE, and N, with the exception of improved CATTD of DM of pigs fed diet supplemented with $0.2 \% \beta$-glucan compared with that of pigs fed nonsupplemented diet at week 6 . Partly in line with our results, Hahn et al. (2006) also indicated that dietary $\beta$-glucan supplementation $(0,0.01,0.02,0.03$, or $0.04 \%$ ) linearly increased DM, GE, and crude protein digestibility in weaner pigs. 
The increase in DM digestibility is a possible reason for the improved growth performance of pigs fed diet supplemented with $0.2 \% \beta$-glucan when compared with nonsupplemented diet. In contrast, Sweeney et al. (2012) found that $\beta$-glucans derived from Laminaria digitata, Laminaria hyperborea or Saccharomyces cerevisiae did not affect DM, N, and GE digestibility in young pigs. Additionally, some previous studies showed that $\beta$-glucan supplementation had no effect on nutrient digestibility in growing (Ko et al., 2000) and finishing pigs (Bae et al., 1999).

Several previous studies indicated that $\beta$-glucan had beneficial effects on pigs' immune function (Li et al., 2005; Li et al., 2006; Volman et al., 2008; Zhou et al., 2013). Wang et al. (2008 b) indicated that peripheral blood lymphocyte proliferation activity was increased by $\beta$-glucan. In lipopolysaccharide challenged weaner pigs, Zhou et al. (2013) observed that dietary $\beta$-glucan enhanced the lymphocyte proportions. However, in the present study, RBC, WBC, lymphocyte, and IgG concentrations were not affected by dietary treatments. Similarly, Hiss and Sauerwein (2003) and Mao et al. (2005) reported that dietary $\beta$-glucan had no effect on lymphocyte proliferation in weaner pigs. In agreement with our findings, in broilers, Zhang et al. (2012) also observed that $\beta$-glucan supplementation did not affect blood RBC, WBC, lymphocyte, and IgG concentrations.

Generally, weaning is associated with diarrhea due to various weaning stresses from nutritional, social, and immunological changes, especially in the first two weeks after weaning (Kim et al., 2012; Fouhse et al., 2015). In the present experiment, fecal scores, fecal moisture, and fecal $\mathrm{pH}$ were not influenced by $\beta$-glucan or Tiamulin supplementation. Similarly, Wang et al. (2008 a) reported that diarrhea rate was not affected by $\beta$-glucan supplementation. Metzler-Zebeli et al. (2011) observed that oat $\beta$-glucan did not affect gastric, cecal and colonic digesta $\mathrm{pH}$. The lack of responses of fecal scores, fecal $\mathrm{pH}$, and fecal moisture to $\beta$-glucan or Tiamulin may be due to the general good hygienic condition of this experiment.

Prebiotics can beneficially affect the host by selectively stimulating the growth and/or activity of beneficial bacteria, including Bifidobacteria and Lactobacilli (Jaskari et al., 1998; Bosscher et al., 2006; Lallès et al., 2007; Arena et al., 2014). The growth of beneficial bacteria may show an inhibition of the proliferation of pathogenic, harmful organisms like Escherichia coli (Huang et al., 2004). In the present study, administration of $\beta$-glucan at the level of $0.2 \%$ increased lactic acid bacteria but decreased coliform bacteria concentrations. Metzler-Zebeli et al. (2011) reported that Lactobacillus numbers in stomach and colon were increased when $8.95 \%$ oat $\beta$-glucan was included in the diet for weaner pigs. Zhou et al. (2013) found that dietary $\beta$-glucan decreased the numbers of Escherichia coli in feces, although Lactobacillus population was not affected in weaner pigs. The improved microbial balance (increased lactic acid bacteria and decreased coliform bacteria) may help to explain the improved growth performance and DM digestibility in pigs fed diet supplemented with $0.2 \% \beta$-glucan.

In conclusion, dietary supplementation with $0.2 \% \beta$-glucan increased the ADG, G:F, DM digestibility, and fecal lactic acid bacteria and decreased fecal coliform bacteria counts, indicating that $\beta$-glucan could be a promising alternative to AGPs in weaner pigs. 


\section{References}

AOAC (2007). Official methods of analysis of AOAC International. 18th ed. AOAC International, Gaithersburg, MD, USA.

Arena M.P., Caggianie 11 o G., F i o c co D., Rus s o P., Tore 11 i M., Spano G., Capozz i V. (2014). Barley $\beta$-glucans-containing food enhances probiotic performances of beneficial bacteria. Int. J. Mol. Sci., 15: 3025-3039.

B a e K.H., K o T.G., K i m J.H., C h o W.T., H a n Y.K., H a n I.K. (1999). Use of metabolically active substances to substitute for antibiotics in finishing pigs. Kor. J. Anim. Sci., 41: 23-30.

B o s s cher D., Van L o o J., Franck A. (2006). Inulin and oligofructose as prebiotics in the prevention of intestinal infections and diseases. Nutr. Res. Rev., 19: 216-226.

Cheng G., H a o H., Xi e S., Wang X., Da i M., H u a n g L., Yu a n Z. (2014). Antibiotic alternatives: the substitution of antibiotics in animal husbandry? Front. Microbiol., 5: 217.

Cho J.H., K i m I.H. (2015). Effects of lactulose supplementation on growth performance, nutrient digestibility, blood profiles, faecal microbial shedding, faecal score and faecal noxious gas emission in weanling pigs. J. Appl. Anim. Res., 43: 330-335.

Dritz S.S., Shi J., Ki elian T.L., Go odband R.D., N els se n J.L., Tok a ch M.D., Cheng a p p a M.M., B l e c h a F. (1995). Influence of dietary beta-glucan on growth performance, nonspecific immunity, and resistance to Streptococcus suis infection in weanling pigs. J. Anim. Sci., 73: 3341-3350.

Ducatelle R., Eeckhaut V., Hae sebrouck F., Van Immerseel F. (2015). A review on prebiotics and probiotics for the control of dysbiosis: present status and future perspectives. Animal, 9: $43-48$.

F e n t o n T.W., F e n t o n M. (1979). An improved procedure for the determination of chromic oxide in feed and feces. Can. J. Anim. Sci., 59: 631-634.

Fouhs e J.M., Gänzle M.G., Re gmi P.R., van Kempen T.A., Zijlstra R.T. (2015). High amylose starch with low in vitro digestibility stimulates hindgut fermentation and has a bifidogenic effect in weaned pigs. J. Nutr., 145: 2464-2470.

Hahn T.W., L o hak are J.D., L e e S.L., Moon W.K. Cha e B.J. (2006). Effects of supplementation of $\beta$-glucans on growth performance, nutrient digestibility, and immunity in weanling pigs. J. Anim. Sci., 84: 1422-1428.

Harris L. E. (1970). Nutrition research techniques for domestic and wild animals, Vol. 1. Utah State University, Logan, UT. USA.

H i s s S., S a u e r w e in H. (2003). Influence of dietary ß-glucan on growth performance, lymphocyte proliferation, specific immune response and haptoglobin plasma concentrations in pigs. J. Anim. Physiol. Anim. Nutr., 87: 2-11.

Huang C., Qia o S., Li D., P i a o X., R en J. (2004). Effects of lactobacilli on the performance, diarrhea incidence, VFA concentration and gastrointestinal microbial flora of weaning pigs. AsianAust. J. Anim. Sci., 17: 401-409.

Huff G.R., Huff W.E., R a th N.C., Tellez G. (2006). Limited treatment with $\beta$-1,3/1,6-glucan improves production values of broiler chickens challenged with Escherichia coli. Poultry Sci., 85: 613-618.

Jaskari J., Kontula P., Si itonen A., Jousimies-Somer H., Mattila-S a d holm T., P o u t a n e n K. (1998). Oat $\beta$-glucan and xylan hydrolysates as selective substrates for Bifidobacterium and Lactobacillus strains. Appl. Microbiol. Biotechnol., 49: 175-181

K e Y.L., J i a o L.F., S ong Z.H., X i a o K., L a i T.M., L u J.J., H u C.H. (2014). Effects of cetylpyridinium-montmorillonite, as alternative to antibiotic, on the growth performance, intestinal microflora and mucosal architecture of weaned pigs. Anim. Feed Sci. Technol., 198: 257-262.

K i m J.C., H ans e n C.F., Mulla n B.P., P l u s ke J.R. (2012). Nutrition and pathology of weaner pigs: nutritional strategies to support barrier function in the gastrointestinal tract. Anim. Feed Sci. Technol., 173: 3-16.

K o T.G., K i m J.D., H a n Y.K., H a n I.K. (2000). Study for the development of antibiotics-free diet for growing pigs. Kor. J. Anim. Sci., 42: 45-54.

L a 11 è s J., B o s i P., S m i d t H., S t o k e s C.R. (2007). Nutritional management of gut health in pigs around weaning. Proc. Nutr. Soc., 66: 260-268. 
L e v y S. (2014). Reduced antibiotic use in livestock: how Denmark tackled resistance. Environ. Health Perspect., 122: A160-A165.

L i J., X ing J., Li D., Wang X., Z h a o L., L v S., H u a n g D. (2005). Effects of $\beta$-glucan extracted from Saccharomyces cerevisiae on humoral and cellular immunity in weaned piglets. Arch. Anim. Nutr., 59: 303-312.

Li J., Li D.F., Xing J.J., Cheng Z.B., La i C.H. (2006). Effects of $\beta$-glucan extracted from Saccharomyces cerevisiae on growth performance, and immunological and somatotropic responses of pigs challenged with Escherichia coli lipopolysaccharide. J. Anim. Sci., 84: 2374-2381.

M a o X.F., P i a o X.S., L a i C.H., L i D.F., X in g J.J., S h i B.L. (2005). Effects of $\beta$-glucan obtained from the Chinese herb Astragalus membranaceus and lipopolysaccharide challenge on performance, immunological, adrenal, and somatotropic responses of weanling pigs. J. Anim. Sci., 83: 2775-2782.

Mendel M., Chłopecka M., Dziekan N., Karlik W. (2017). Phytogenic feed additives as potential gut contractility modifiers - a review. Anim. Feed Sci. Technol., 230: 30-46.

Metzler-Zebeli B.U., Zijlstra R.T., M os enth in R., Gänzle, M.G. (2011). Dietary calcium phosphate content and oat $\beta$-glucan influence gastrointestinal microbiota, butyrate-producing bacteria and butyrate fermentation in weaned pigs. FEMS Microbiol. Ecol., 75: 402-413.

Metzler-Zebeli B.U., Gänzle M.G., Mosenthin R., Zijlstra R.T. (2012). Oat $\beta$-glucan and dietary calcium and phosphorus differentially modify intestinal expression of proinflammatory cytokines and monocarboxylate transporter 1 and cecal morphology in weaned pigs. J. Nutr., 142: 668-674.

Murphy P., Dal Bello F., O 'D oherty J., A rendt E.K., S weeney T., Coffey A. (2013). Analysis of bacterial community shifts in the gastrointestinal tract of pigs fed diets supplemented with $\beta$-glucan from Laminaria digitata, Laminaria hyperborea and Saccharomyces cerevisiae. Animal, 7: 1079-1087.

NRC (2012). Nutrient Requirements of Swine, 11th rev. ed. Natl. Acad. Press, Washigton, DC, USA.

O'She a C.J., Mc Alpine P., S weeney T., Varley P.F., O'Doherty J.V. (2014). Effect of the interaction of seaweed extracts containing laminarin and fucoidan with zinc oxide on the growth performance, digestibility and faecal characteristics of growing piglets. Brit. J. Nutr., 111: 798-807.

S a 1 i m H.M., K a ng H.K., A kt e r N., K i m D.W., K im J.H, K i m M.J., N a J.C., J on g H.B., C h o i H.C., S u h O.S., K i m W.K. (2013). Supplementation of direct-fed microbials as an alternative to antibiotic on growth performance, immune response, cecal microbial population, and ileal morphology of broiler chickens. Poultry Sci., 92: 2084-2090.

Sweeney T., Collins C.B., Reilly P., P i erce K.M., Ry an M., O 'D oherty J.V. (2012). Effect of purified $\beta$-glucans derived from Laminaria digitata, Laminaria hyperborea and Saccharomyces cerevisiae on piglet performance, selected bacterial populations, volatile fatty acids and pro-inflammatory cytokines in the gastrointestinal tract of pigs. Brit. J. Nutr., 108: 1226-1234.

Tha cker P.A. (2013). Alternatives to antibiotics as growth promoters for use in swine production: a review. J. Anim. Sci. Biotechnol., 4: 35.

Volman J.J., Ramarkers J.D., Plat J. (2008). Dietary modulation of immune function by $\beta$-glucans. Physiol. Behav., 94: 276-284.

W a n g Z., Gu o Y., Yu an J., Z hang B. (2008 a). Effect of dietary $\beta$-1,3/1,6-glucan supplementation on growth performance, immune response and plasma prostaglandin E2, growth hormone and ghrelin in weanling piglets. Asian-Aust. J. Anim. Sci., 21: 707-714.

Wang Z., Sha o Y., Gu o Y., Yuan J. (2008 b). Enhancement of peripheral blood CD8+ T cells and classical swine fever antibodies by dietary $\beta-1,3 / 1,6$-glucan supplementation in weaned piglets. Transbound. Emerg. Dis., 55: 369-376.

W illi a m s C.H., D a vid D.J., I is ma O O. (1962). The determination of chromic oxide in faeces samples by atomic absorption spectrophotometry. J. Agric. Sci., 59: 381-385.

Zhang Z.F., Zhou T.X., A o X., K im I.H. (2012). Effects of $\beta$-glucan and Bacillus subtilis on growth performance, blood profiles, relative organ weight and meat quality in broilers fed maizesoybean meal based diets. Livest. Sci., 150: 419-424.

Z h o u T.X., J u n g J.H., Z h a n g Z.F., K i m I.H. (2013). Effect of dietary $\beta$-glucan on growth performance, fecal microbial shedding and immunological responses after lipopolysaccharide challenge in weaned pigs. Anim. Feed Sci. Technol., 179: 85-92. 